\section{Penamaan Objek Wisata di Wilayah Kabupaten Kuningan Jawa Barat}

Didit Aditya

Linguistics Master Program,

Universitas Gadjah Mada

diditaditya@mail.ugm.ac.id

\begin{abstract}
ABSTRAK
Kabupaten Kuningan terletak di ujung timur provinsi Jawa Barat, tepatnya berada di kaki gunung Ciremai yang merupakan gunung tertinggi di Jawa Barat. Secara geografis letak Kabupaten Kuningan sangat strategis karena berada di perbatasan antara dua provinsi yaitu provinsi Jawa Barat dan Jawa Tengah. Keindahan panorama alam, keunikan seni dan budayanya sebagai daya tarik bagi para wisatawan. Didukung dengan akses yang mudah serta infrastruktur yang memadai, Kabupaten Kuningan menjadi daerah tujuan wisata yang menarik. Dengan potensi wisata yang berlimpah keindahan alam pegunungan dan keunikan seni budaya sebagai potensi wisata, pemerintah Kabupaten Kuningan terus berupaya melakukan promosi melalui berbagai media. Pada sector wisata Kuningan merupakan salah satu wilayah yang memiliki banyak potensi alam. Di wilayah ini terdapat banyak objek wisata dengan pusatnya Gunung Ciremai sebagai salah satu Taman Nasional, pemandian air panas, wisata budaya, wisata sejarah, wisata religi dan lain-lain. Penamaan objek wisata merupakan salah satu hal terpenting yang tidak bisa dilewatkan begitu saja, nama yang menarik bahkan unik merupakan salah satu faktor yang akan membuat wisatawan penasaran dan tertarik untuk berkunjung. Objek penelitian yang digunakan adalah nama-nama objek wisata yang ada di wilayah Kabupaten Kuningan dengan analisis yang digunakan adalah etnosemantik untuk mengungkap asal usul dan latar belakang penamaan objek wisata di Kabupaten Kuningan. Penelitian ini bertujuan untuk mendeskripsikan bentuk satuan kebahasaan dalam penamaan, proses penamaan dan dinamika nama-nama objek wisata di wilayah Kabupaten Kuningan Jawa Barat. Metode pengumpulan data yang digunakan adalah metode kualitatif melalui observasi dan wawancara yang mendalam kepada beberapa informan dan objek penelitian. Hasil penelitian menunjukkan bahwa bentuk nama-nama objek wisata di Kabupaten Kuningan mempunyai bentuk kebahasaan tersendiri, yang meliputi Bahasa Sunda, Bahasa Indonesia, dan beberapa menggunakan bahasa Inggris. Nama-nama objek wisata juga dipengaruhi oleh tiga aspek dalam penamaan, yaitu: aspek perwujudan, aspek kemasyarakatan, dan aspek kebudayaan. Makna yang terkandung dalam nama-nama objek wisata di wilayah Kabupaten Kuningan lebih banyak dikarenakan unsur kebudayaan. Terdapat dinamika nama-nama objek wisata di Kabupaten Kuningan dengan tujuan untuk menarik wisatawan.
\end{abstract}

Kata kunci: Penamaan; Wisata; Kuningan

\title{
PENDAHULUAN
}

Dalam interaksi sosial manusia dapat memberikan nama-nama terhadap benda-benda atau suatu keadaan dalam lingkungan tertentu sebagai suatu identitas, misalkan nama-nama benda, nama orang, nama tumbuhan, nama hewan, dan nama tempat atau daerah. Penamaan nama tempat tidak terlepas dari bahasa dan asal muasal dari suatu daerah tersebut. Menurut Kridalaksana (2008:160), penamaan merupakan proses pencarian lambang bahasa untuk menggambarkan objek, konsep, proses, dan sebagainya. Proses ini biasanya dilakukan dengan memanfaatkan kata-kata yang ada, seperti halnya dengan perubahan-perubahan makna yang mungkin terjadi atau dengan mengkreasikan kata atau kalimat.

Kabupaten Kuningan mempunyai keindahan alam dan peninggalan budaya masa lampau sebagai modal besar pengembangan kepariwisataan Kabupaten Kuningan, yang tidak dapat dipisahkan dari tradisi dan budaya yang telah menjadi bagian dari kehidupan masyarakat yang bercorak agraris. Potensi ini ditambah lagi dengan kesuburan tanah, kesejukan udara, letak geografis dan tofografisnya serta lingkungan hidup yang sangat menunjang usaha pengembangan potensi daerah Kabupaten Kuningan. 
Potensi objek wisata di Kabupaten Kuningan Jawa Barat terdiri dari Wisata Alam, Wisata Budaya dan Wisata Buatan. Potensi-potensi alam yang ada sebagian telah dikembangkan sebagai objek wisata sebagian lagi potensi alamnya masih diperlukan perencanaan untuk mengembangkannya. Perencanaan yang baik diperlukan agar potensi yang ada mampu berkembang sebagai daya tarik wisata dan mendatangkan wisatawan dalam tahap perencanaan ditekankan pada penciptaan keanekaragaman objek dan atraksi wisata yang berada pada masing-masing kawasan wisata. Salah satu tahap dalam proses perencanaan adalah proses penamaan objek wisata. Penamaan objek wisata merupakan salah satu hal terpenting yang tidak bisa dilewatkan begitu saja. Nama yang menarik bahkan unik merupakan salah satu faktor yang akan membuat wisatawan penasaran dan tertarik untuk berkunjung.

Masyarakat Kabupaten Kuningan menggunakan bahasa kesehariannya yaitu bahasa Sunda yang berdampak besar dalam proses penamaan objek wisata di Kabupaten Kuningan. Banyak terdapat nama-nama objek wisata di Kabupaten Kuningan yang menggunakan bahasa Sunda, seperti Palutungan, Talaga Surian, Bungkirit, Cibulan, Ampah Nangka, Mumunggang Tenjo Laut, Curug Ngelay dan Balong Cigugur. Terjadi perubahan makna untuk penamaan dapat dilihat dari nama Palutungan yang dijadikan salah satu nama objek wisata alam di daerah Cigugur. Ada dua versi mengenai latar belakang penamaan Palutungan. Yang pertama, Palutungan berasal dari Bahasa sunda panungtung yang artinya ujung, adalah suatu blok atau kampung yang lokasinya berasa diujung desa. Sehingga tempat tersebut dinamakan Palutungan. Selain itu sebagian masyarakat juga berpendapat bahwa nama Palutungan berasal dari kata Lutung yaitu nama primata sejenis kera yang berwarna hitam. Sebab konon katanya dahulu di daerah tersebut terdapt banyak kawanan kera jenis lutung. Kata Palutungan sendiri berasal dari kata dasar Lutung. Berawalan pa- dan berakhiran -an yang artinya menandakan tempat. Pada objek wisata tersebut wahana yang ditawarkan adalah bentuk keidahan alam yang berupa pemandangan perbukitan, daratan yang berundak-undak sangat cocok dijadikan tempat untuk berkemah, dan terdapat air terjun yang dinamai Curug Ciputri. Selain itu terdapat nama objek wisata lain yaitu Curug Ngelay (dalam bahasa Indonesia Air Terjun yang menyerupai air liur). Hal ini dikarenakan ciri fisik air terjun tersebut menyerupai air liur maka tempat tersebut dinamai Curug Ngelay.

Penamaan objek wisata di Kabupaten Kuningan ini bisa dipengaruhi oleh berbagai hal, salah satu diantaranya adalah faktor lingkungan. Ketika lingkungan tersebut terdapat banyak sumber air, maka penamaan tempatpun tidak akan jauh dari air. Seperti misalnya Balong dalem, Balong Cigugur, Talaga Biru, Balong Darmaloka, dan Situ Wulukut. Terdapat juga nama-nama objek wisata di wilayah Kabupaten Kuningan menggunakan nama-nama yang bersifat fauna, seperti Palutungan, Talaga Nilem, Sidomba, Curug Bangkong dan Goa Walet.

Perkembangan wisata di Kabupaten Kuningan sangat berkembang pesat, hal ini disebabkan karena masih banyak tempat di Kabupaten Kuningan yang berpotensi untuk dijadikan objek wisata. Perkembangan dunia teknologi dengan sosial medianya secara tidak langsung menyebarkan informasi mengenai tempat-tempat menarik yang ada di wilayah Kabupaten Kuningan sehingga membuat penasaran dan mengundang banyak wisatawan untuk berkunjung. Hal inilah yang membuat masyarakat Kabupaten Kuningan giat membuka objek wisata baru dengan menamai mereka secara unik dan menarik untuk mengundang para pengunjung. Dari phenomena tersebut terjadilah dinamika nama-nama objek wista baru yang bersifat kekinian dengan menggunakan bahasa Inggris karena dianggap keren misalnya The Wood Land, lahan tandus menjadi Open Space Gallery Linggarjati, Starcamp-Langit Resto, batu luhur menjadi Rock Garden Batu Luhur, sangkan hurip menjadi Sangkan Resort Aqua Park, dan The Mountain Recreation Park.

Dengan mengetahui latar belakang kebudayaan masyarakat Kabupaten Kuningan peneliti berharap bisa mengetahui makna yang terkandung di dalam panamaan tersebut. Menurut Foley bahwa mempelajari bahasa dalam konteks budaya secara mendalam dan berusaha mencari makna tersembunyi yang ada di balik pemakaian bahasa. Berdasarkan penjelasan di atas, rumusan masalah yang diajukan oleh peneliti adalah sebagai berikut. (1) Apa bentuk satuan kebahasaan dalam penamaan objek wisata di Kabupaten Kuningan Jawa Barat? (2) Bagaimana makna proses penamaan objek wisata di Kabupaten Kuningan Jawa Barat? Berdasarkan rumusan masalah yang disebutkan di atas, maka tujuan penelitian ini adalah yang pertama, umtuk mendeskripsikan bentuk satuan kebahasaan dalam penamaan objek wisata di Kabupaten Kuningan Jawa Barat. Dan yang kedua 
adalah untuk mendeskripsikan makna penamaan objek wisata di Kabupaten Kuningan Jawa Barat. Diharapkan penelitian ini bisa bermanfaat baik secara teoritis dan praktis. Secara teoritis, penelitian ini dilakukan untuk menjelaskan aspek penamaan yang digunakan untuk memberikan sebuah nama pada objek wisata di Kabupaten Kuningan dengan sudut pandang dan latar belakang budaya setempat. Secara praktis, penelitian ini dapat menambah wawasan keilmuan mengenai studi linguistik. Serta merupakan bentuk pendataan terhadap nama-nama objek wisata di Kabupaten Kuningan Jawa Barat. Dengan demikian, diharapkan peneliti ini dapat menjadi sumber tertulis bagi masyarakat Kabupaten Kuningan khususnya dan juga merupakan kontribusi sebagai anak daerah ikut mengembangkan informasi mengenai objek wisata di Kabupaten Kuningan kepada masyarakat umum lainnya.

Penelitian ini difokuskan pada satu daerah penelitian, yaitu di wilayah Kabupaten Kuningan Jawa Barat yang meliputi 7 Kecamatan yang terdapat banyak objek wisata yaitu Kecamatan Kuningan, Kecamatan Cigugur, Kecamatan Jalaksana, Kecamatan Kramatmulya, Kecamatan Ciniru, Kecamatan Ciwaru, dan Kecamatan Mandirancan. Kabupaten Kuningan dipilih karena merupakan Kabupaten kecil namun kaya akan potensi alam yang bisa dijadikan pusat penelitian tentang penamaan objek wisata di Kabupaten Kuningan.

Kajian tentang penamaan dititik beratkan pada nama-nama objek wisata saja. Data yang digunakan berupa nama-nama objek wisata yang berdasarkan data Dinas Kepemudaan, Olahraga dan Pariwisata Kabupaten Kuningan maupun dari narasumber lainnya dari beberapa tempat di Kbaupaten Kuningan. Fikus penelitian ini adalah bentuk-bentuk satuan kebahasaan, aspek budaya, dan proses perubahan penamaan objek wisata dari tahun ke tahun.

Sebelum menyusun penelitian ini, penulis mengumpulkan beberapa kepustakaan yang berkaitan. Terdapat penelitian sebelumnya yang relevan yaitu penelitian dalam disertasi milik Tedi Permadi yang ditulis pada tahun 2012 dalam judul "Toponimi Jalan Raya di Kota Bandung". Tujuan penelitian ini untuk (1) menjelaskan alasan dipergunakannya sebuah nama jalan; (2) berlangsungnya proses pemberian nama jalan; dan (3) kaitan antara latar belakang aspek hidrologis, biologis, dan sosiokultural dengan nama jalan yang dipakai. Pada penelitian ini, penelusuran nama sebuah jalan dikaitkan dengan unsur-unsur nama lainnya. Untuk mengetahui informasi yang terkandung di balik sebuah nama jalan, dihubungkan dengan aspek-aspek fisikal, sosial maupun budaya di lingkungan masyarakat. Pola pertama dapat ditinjau dan dihubungkan dengan fenomena alam yang pernah terjadi. Pola kedua dapat diadaptasi dari gabungan beberapa aspek, seperti gabungan antara gejala alam dengan gejala sosial. Pola ketiga diadaptasi dari gejala sosial. Data pada penelitian ini diperoleh dari Dinas Perkotaan Bandung. Hasil dari penelitian ini adalah nama-nama jalan dan daerah di Bandung berhubungan dengan air, tempat bermukim, tanah kosong dan tanah yang ditanami, ciri alam, bangunan tua yang memiliki nilai sejarah, nama tokoh tertentu, nama pulau-pulau, kota, tokoh wayang, dan nama burung.

Penelitian selanjutnya, berupa tesis yang ditulis oleh Alifa Mardhoniawati pada tahun 2016 yang berjudul "Toponimi Desa-desa di Provinsi Lampung: Sebuah Kajian Linguistik Antropologi". Penelitian ini bertujuan untuk (1) mengidentifikasi bentuk satuan kebahasaan toponim desa-desa di Provinsi lampung; (2) mengidentifikasi kategorisasi toponim desa-desa di Provinsi lampung berdasarkan makna toponim; (3) menganalisis perbedaan karakteristik toponim pada setiap variabel penelitian. Penelitian ini membahas tentang aspek liguistik dan karakteristik pemilik budaya yang melatarbelakangi pembentukan toponimi di Provinsi Lampung. Dari penelitian yang dilakukan, didapatkan hasil sebagai berikut (1) bentuk satuan kebahasaan yang ditemukan adalah leksem dengan satu atau dua morfem, serta gabungan yang ditemukan adalah leksem dengan satu dan dua morfem, serta gabungan leksem dengan dua, tiga dan empat leksem; (2) kategori makna toponimi desa-desa di Provinsi Lampung terdiri atas (a) aspek perwujudan (wujud air, wujud muka bumi, flora, fauna, pola permukiman, dan adopsi nama/unsur benda alam), (b) aspek kemasyarakatan (profesi, kegiatan, komunitas, harapan, adopsi nama/unsur bangunan), (c) aspek kebudayaan (folklor, religi, tangiable culture, dan intangiable culture), dan (d) aspek kombinasi. (3) dengan menggunakan kajian linguistik antropologi, tampak perbedaan karaktristik masing-masing variabel. Toponimi Lampung banyak menggunakan kata-kata sifat yang berasosiasi dengan kebesaran, keagungan, kekayaan, kedigdayaan, kemuliaan, baik pada nama tempat maupun pada nama diri seseorang. Toponimi Jawa dan Sunda dominan menggunakan nama yang sama persis dengan nama desa di Pulau Jawa. 
Toponimi Bali menggunakan bahasa Sanskerta yang menunjukkan bakti kepada Ida Hyung Wdhi, dharma, budaya, dan harapan pada tanah baru.

Dalam sebuah seminar internasional Dede Kosasih pada tahun 2010 menyajikan sebuah penelitian dengan judul —Kosmologi Sistem Nama Diri (antroponim) Masyarakat Sunda: dalam Konstelasi Perubahan Struktur Sosial Budaya. Dalam penelitiannya difokuskan untuk menyoroti pola pemberian nama pada masyarakat sunda secara diakronis dengan membandingkan masa bihari dan masa kiwari, termasuk bagaimana hubungan nama, makna, dan implikasi sebuah nama. Dari kajiannya tersebut diperoleh hasil bahwa penamaan terkait erat dengan (a) dinamika masyarakat yang meningkat, (b) perkembangan kosa kata bahasa manusia sebagai buah dari komunikasi peradaban, (c) perkembangan nalar (akal budi) dan pola pikir manusia, (d) perkembangan sikap mental dan respon budaya masyarakat, (e) perkembangan kebutuhan manusia, dan yang tidak dapat dilupakan adalah (f) jasa ilmu pengetahuan dan teknologi melalui hasil-hasilnya.

Dari beberapa penelitian di atas mengkaji toponimi dari struktur bahasa dan semantik. Penelitian ini juga didasarkan pada pemaparan struktur bahasa dan semantik yang terdapat dalam toponimi. Yang membuat penelitian ini berbeda dengan penelitian sebelumnya adalah yang pertama, penelitian ini dilakukan di daerah Kabupaten Kuningan. Kedua, menjabarkan struktur bahasa dan makna pada toponimi objek wisata Kabupaten Kuningan yang berkaitan dengan aspek sosial dan budaya yang menjadi salah satu latar belakang penamaan objek wisata di Kabupaten Kuningan. Secara garis besar penelitian ini hanya berfokus pada penamaan ikan objek wisata di Kabupaten Kuningan Jawa Barat dan latar belakang yang ada.

Nama merupakan kata-kata yang menjadi identitas setiap makhluk, benda, aktivitas, dan peristiwa di dunia ini. Anak-anak mendapat kata-kata dengan cara belajar, dan menirukan bunyi-bunyi yang mereka dengar untuk pertama kalinya. Nama-nama ini muncul akibat dari kehidupan manusia yang kompleks dan beragam, alam sekitar manusia berjenis-jenis. Kadang-kadang muncul nama-nama kelompok, misalkan binatang, burung, ikan, dan tumbuh-tumbuhan (tak terhitung jumlah jenis binatang, jenis burung, jenis tumbuhan yang ada di dunia ini). Penamaan di tiap daerah atau lingkungan kebudayaan tertentu bagi benda yang sama tentunya berbeda. Misalkan kata Pepaya (Bahasa Indonesia) berbeda dengan gedang (Bahasa Sunda). Masalah yang muncul sehubungan dengan perbedaan nama tersebut ialah apakah hubungan nama dengan benda. (Djajasudarma,1993:30-31). Masalah yang muncul sehubungan dengan nama, apakah nama ada hubungannya dengan istilah, definisi bahkan arti. Nama berupa kata atau kata-kata yang merupakan identitas dari makhluk, benda, aktivitas, dan peristiwa (seperti dinyatakan terdahulu). Istilah adalah nama tertentu yang bersifat khusus atau suatu nama yang berisi kata atau gabungan kata yang cermat, mengungkapkan makna, konsep, proses, keadaan, atau sifat yang khas di bidang tertentu. Definisi adalah nama yang diberi keterangan singkat dan jelas di bidang tertentu. Suatu nama dapat berfungsi sebagai istilah; istilah-istilah akan menjadi jelas bila diberi definisi, demikian pula nama. Istilah sama halnya dengan definisi, keduanya berisi pembatasan tentang suatu fakta, peristiwa atau kejadian, dan proses (Djajasudarma,1993:32).

Menurut pandangan Thatcher (dalam Sugiri, 2009:4) ada tujuh aturan pemberian nama, yaitu: (1) nama harus berharga, (2) nama harus mengandung makna yang baik; (3) nama harus asli, (4) nama harus mudah dilafalkan, (5) nama harus bersifat membedakan, (6) nama harus cocok dengan nama keluarga, (7) nama harus menunjukkan jenis kelamin. Selain itu, nama harus mempunyai nilai praktis dan magis. Tujuh aturan pemberian nama ini, ditujukan bagi pemberian nama pada manusia. Tetapi, bisa juga digunakan untuk pemberian nama tempat dengan menghilangkan unsur keenam dan ketujuh. Menurut Chaer (2002:43) penamaan dan pendefinisian adalah dua proses pelambangan suatu konsep untuk mengacu kepada sesuatu referen yang berada di luar bahasa. Sesuai hakikat bahasa, bahasa adalah sistem lambang bunyi yang bersifat arbitrer. Antara satuan bahasa sebagai lambang, misalnya kata dengan sesuatu benda atau hal yang dilambangkannya bersifat sewenangwenang tidak ada hubungan wajib di antara keduanya. Jika nama merupakan hal yang sama dengan lambang untuk sesuatu yang dilambangkannya, berarti pemberian nama itu pun bersifat arbitrer, tidak ada hubungan wajib sama sekali. Aristoteles pernah menyebutkan bahwa pemberian nama adalah soal konvensi atau perjanjian belaka di antara sesama anggota suatu masyarakat bahasa. Meskipun demikian, kita masih bisa menelusuri sebab-sebab atau peristiwa-peristiwa yang melatarbelakangi terjadinya penamaan atau penyebutan terhadap sejumlah kata. 
Menurut Sudaryat (2009: 12-19) penamaan atau toponimi memiliki tiga aspek, yaitu 1) aspek perwujudan; (2) aspek kemasyarakatan; dan (3) aspek kebudayaan. Ketiga aspek tersebut sangat berpengaruh terhadap cara penamaan tempat dalam kehidupan masyarakat.

1. Aspek Perwujudan

Aspek perwujudan (fisikal) berkaitan dengan kehidupan manusia yang cenderung menyatu dengan bumi sebagai tempat berpijak dan lingkungan alam sebagai tempat hidupnya. Sudaryat membagi lingkungan alam tersebut ke dalam tiga kelompok, yaitu (1) latar perairan (wujud air); (2) latar rupabumi (geomorfologis) (3) latar lingkungan alam (biologisekologis) (Sudaryat, 2009:1215).

2. Aspek Kemasyarakatan

Aspek kemasyarakatan (sosial) dalam penamaan tempat berkaitan dengan interaksi sosial atau tempat berinteraksi sosial, termasuk kedudukan seseorang di dalam masyarakatnya, pekerjaan, dan profesinya (Sudaryat, 2009:17). Keadaan masyarakat menentukan penamaan tempat, misalnya sebuah tempat yang masyarakatnya mayoritas bertani, maka tempat tinggalnya diberi nama yang tidak jauh dari pertanian. Pemberian nama tempat sesuai dengan seorang tokoh yang terpandang di masyarakatnya juga dapat menjadi aspek dari segi kemasyarakatan dalam menentukan nama tempat.

3. Aspek Kebudayaan

Di dalam penamaan tempat banyak sekali yang dikaitkan dengan unsur kebudayaan seperti masalah mitologis, folklor, dan sistem kepercayaan (religi) pemberian nama tempat jenis ini sering pula dikaitkan dengan cerita rakyat yang disebut legenda (Sudaryat, 2009:18). Banyak sekali nama-nama tempat di Indonesia yang berasal dari legenda yang ada di masyarakatnya.

Menurut Wijana ada tiga aspek penting yang sekurang-kurangnya harus dapat diungkapkan oleh para ahli bahasa dalam melaksanakan setiap tugas penelitian kebahasaannya. Tiga aspek itu adalah bentuk, makna, dan fungsi. Bentuk menyangkut wujud formal satuan lingual, makna menyangkut relasi bentuk dengan konsep dan segala yang ditunjuknya, sedangkan fungsi berhubungan dengan peran sosial yang dijalankan oleh satuan lingual itu di dalam peristiwa komunikasi (Wijana, 2015:1).

Menurut Wijana (2015: 28) makna leksikal adalah makna satuan-satuan kebahasaaan yang dapat diidentifikasikan tanpa satuan itu bergabung dengan satuan lingual lain. Nama pada data yang muncul, beberapa telah mengalami proses morfologis. Proses morfologi yang terjadi menyebabkan makna leksikal berkolaborasi dengan kaidah-kaidah grmatikal, maka makna yang kemudian muncul adalah makna gramatikal. Makna gramatikal adalah berbagai makna yang diungkapkan dengan kaidah-kaidah gramatikal (Wijana, 2015: 29). Sementara berdasarkan pendapat Bowcher terdapat begitu banyak sudut pandang untuk menentukan sebuah makna.

\section{THOUGHT OR REFERENCE}

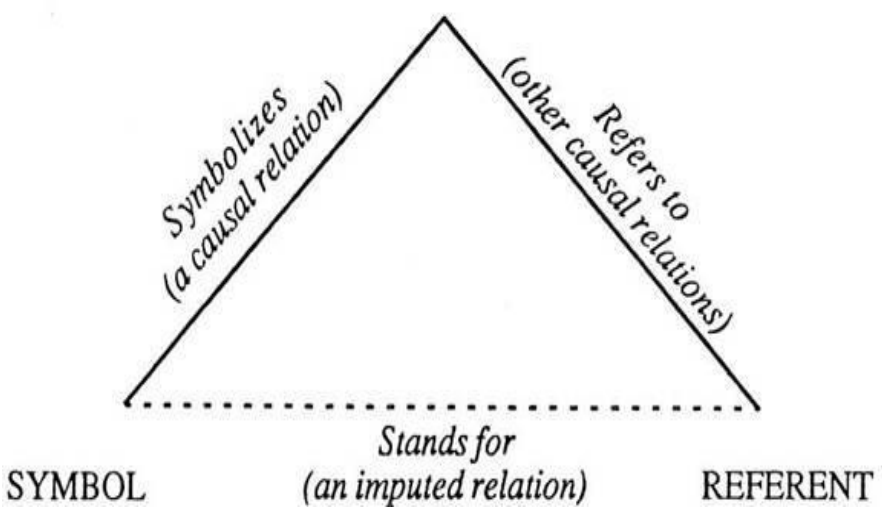

Ini adalah segitiga semantik yang cukup terkenal dari Ogden dan Richards (1923), di mana istilah yang digunakan adalah (a) Symbol, (b) Thought or Reference (c) Referent. Ogden dan Richards telah 
menemukan cara untuk menghubungkan semua kata dengan maknanya. Ada hubungan antara ketiga faktor, diwakili oleh sisi-sisi segitiga. Hubungan antara Thought dan Symbol adalah sebab dan akibat, yang berarti Symbol membangkitkan sikap atau efek pada orang lain. Demikian pula, hubungan antara Thought dan Referent, yang memiliki hubungan langsung. Garis putus-putus pada hubungan antara Symbol dan Referent adalah hubungan tidak langsung karena merupakan hubungan yang arbitrer yang diciptakan oleh seseorang yang menginginkan Symbol untuk merepresentasikan Referent (Ogden dan Richards, 1923). Dengan kata lain Referent tersebut membutuhkan beberapa pengalaman (Thought or Reference) sebelumnya tentang Symbol untuk menjadi komprehensif atau utuh.

Dengan menghubungkan symbol yang terdapat dalam nama-nama objek wisata dengan referent, yaitu sesuatu yang terkandung atau terdapat dalam nama tersebut, dan thought atau makna yang terkandung dalam nama-nama objek wisata.

\section{PEMBAHASAN}

\section{Nama objek wisata di Kabupaten Kuningan yang terdiri atas satu morfem}

Satuan kebahasaan nama-nama objek wisata di Kabupaten Kuningan yang berbentuk leksem yang terdiri atas satu morfem antara lain sebagai berikut.

(1) Mahkota (n)

Penamaan berupa kata monomorfemis pertama adalah Mahkota. Kata Mahkota hanya terdiri dari satu morfem. Menurut KBBI Mahkota merupakan hiasan kepala atau songkok kebesaran bagi raja atau ratu.

(2) Salsabila $(n)$

Penamaan berupa kata monomorfemis yang kedua adalah Salsabila. Kata Salsabila terdiri dari satu morfem. Salsabila berasal dari Bahasa Arab yang artinya adalah 'mata air surga'.

(3) Lambosir ( $n$ )

Penamaan berupa kata monomorfemis yang ketiga adalah Lambosir. Kata Lambosir terdiri dari satu morfem. Lambosir berasal dari Bahasa Sunda yang artinya adalah 'bagian daging dalam yang rasanya enak'.

Nama-nama objek wisata di atas berbentuk leksem yang berdiri sendiri dan terdiri dari morfem tunggal. Jenis yang ditemukan meliputi kata benda ( $n$ ).

\section{Nama objek wisata di Kabupaten Kuningan yang terdiri atas dua morfem}

Satuan kebahasaan nama-nama objek wisata di Kabupaten Kuningan yang berbentuk leksem yang terdiri atas dua morfem antara lain sebagai berikut.
(4) Paniis
Paniis ( $n$ ) dapat diartikan sebagai tempat yang dingin.
(5) Sidomba
Sidomba $(n)$ yang artinya tempat yang terdapat domba.
(6) Ipukan Ipukan ( $\mathrm{n}$ ) adalah tempat yang digunakan untuk menyenai bibit tanaman.
(7) Kagungan Kagungan (n) artinya 'kepunyaan/milik'.
(8) Parakan
Parakan (n) artinya tempat yang biasa dijadikan untuk menangkap ikan.

Pada data nama-nama objek wisata dengan dua morfem, ditemukan pola pembentukan nama dengan cara afiksasi dan kontruksi secara morfologi sehingga membentuk kata baru. Jenis yang ditemukan meliputi kata benda (n), kata kerja (v), dan kata sifat (adj).

\section{Afiksasi pada nama-nama Objek Wisata di Kabupaten Kuningan.}

Afiksasi merupakan proses dimana leksem berubah menjadi kata kompleks. Misalkan diambil contoh leksem 'tari' mengalami proses afiksasi sehingga menjadi 'menari'. Afiksasi yang terjadi pada namanama objek wisata di Kabupaten Kuningan dirincikan pada tabel berikut. 
Penamaan Objek Wisata di Wilayah Kabupaten Kuningan Jawa Barat

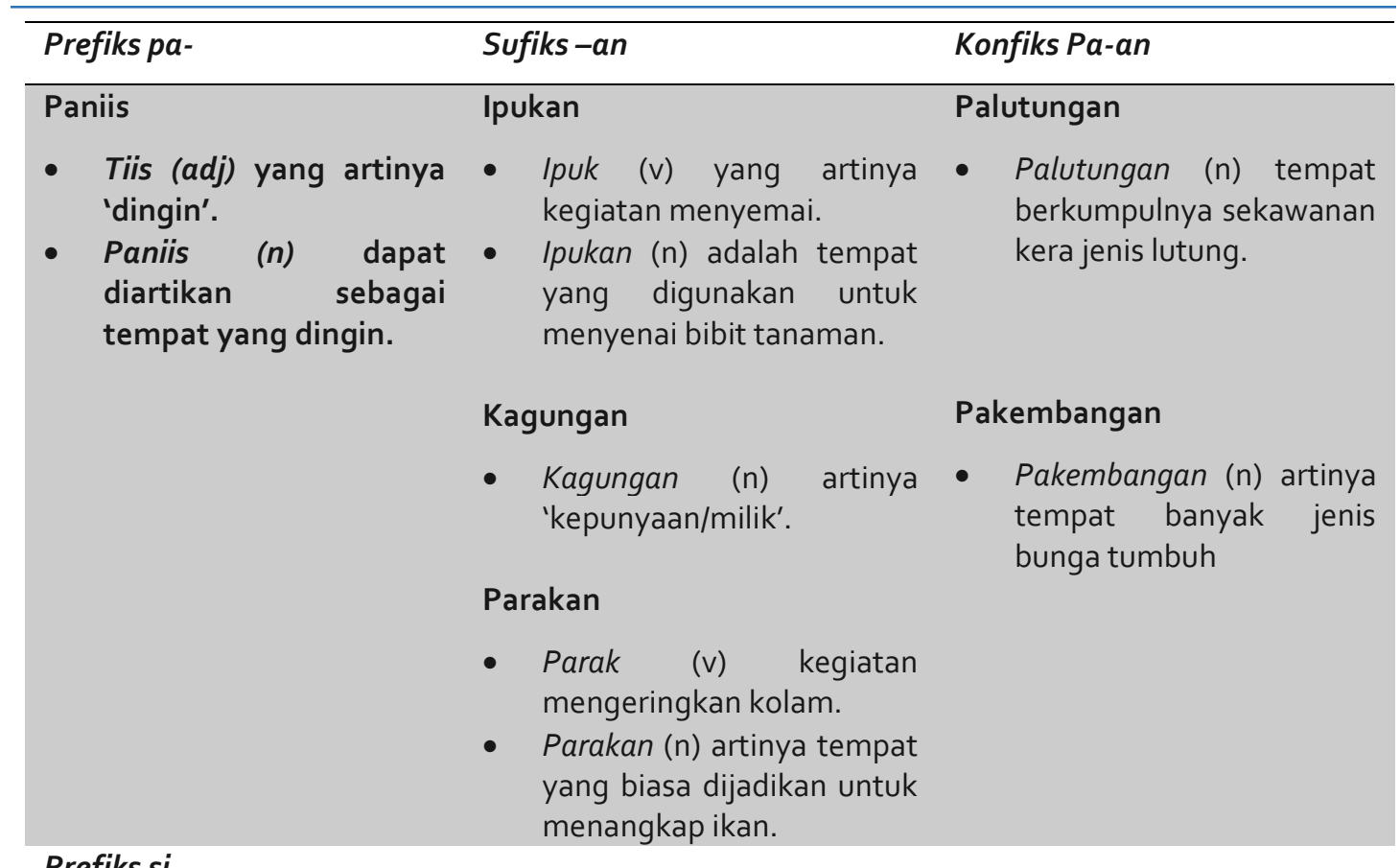

Prefiks si-

Sidomba

Domba (n) yang artinya

kambing berbulu tebal.

Sidomba (n) yang artinya

tempat yang terdapat

domba.

\section{Analisis Makna Penamaan Objek Wisata di wilayah Kabupaten Kuningan}

\section{a. Aspek Perwujudan}

Aspek perwujudan berkaitan erat dengan semua pola kehidupan manusia yang pada dasarnya melekat dengan keadaan alam sebagai intensitasnya komunikasi antara manusia dengan lingkungannya. Dalam aspek perwujudan ini Sudaryat membaginya dalam tiga bentuk, yaitu (1) latar perairan (wujud air); (2) latar rupabumi (geomorfologis); (3) latar lingkungan alam (biologis-ekologis) (Sudaryat, 2009:12-15).

1) Wujud Air

(9) Talaga Remis

Dalam Bahasa Sunda Talaga mempunyai arti situ alam anu jadi ku maneh, lain menang nyieun jelema (LBBS, 2010:464). Dapat diartikan dalam Bahasa Indonesia bahwa Talaga merupakan sebuah kolam yang terbentuk secara alami tanpa campur tangan manusia.

Remis ( $n$ ) karang yang dapat dimakan

(10) Paniis

Paniis berasal dari kata dasar tiis yang artinya dingin, sejuk. Paniis bias diartikan sebagai tempat yang dingin karena banyak terdapat air.

(11) Cibulan

Cibulan secara Bahasa merupakan gabungan dari dua kata, Ci adalah cai yang artinya air. Bulan sendiri diambil dari kata katimbulan yang artinya bermunculan dari kata dasar muncul atau timbul. Jadi secara arti Cibulan merupakan air yang bermunculan dari beberapa mata air. 
Didit Aditya

(12) Zam Zam Pool

Mengadaptasi dari arti Zamzam di Mekah, yang artinya kumpul-kumpul, air yang berlimpah.

(13) Curug Bangkong

Curug adalah cai walungan nu turun kana jurang cara pancuran (LBBS, 2010;1001). Dalam Bahasa Indonesia dikenal dengan nama Air Terjun. Yang artinya adalah aliran air melewati jeram hingga air jatuh bebas ke dasar sungai (lereng, lembah)

(14) Waduk Darma

Waduk adalah kolam besar tempat penyimpan air sediaan untuk berbagai kebutuhan atau mengatur pembagian air dan sebagainya (dipakai di musim kemarau)

2) Wujud Bumi

(15) The Mountain Recreation Park

Nama yang menggunakan Bahasa Inggris yang dilatarbelakangi oleh lokasi yang berada di kaki Gunung Ciremai dan bentuk yang berbukit-bukit menyerupai Gunung.

(16) Rock Garden Batu Luhur

Proses geomorfologis yang diadopsi sebagai penamaan tempat adalah Rock Garden yang artinya adalah Kebun Batu.

(17) Cadas gantung.

Nama yang digunakan adalah kata cadas, yang menurut kamus LBBI merupakan lapisan tanah yang keras; batu yang terbentuk dari padatan pasir atau tanah. Dinamakan Cadas Gantung berdasarkan sebutan masyarakat sekitar yang secara spontan menyebutkannya. Area tersebut biasa mereka gunakan sebagai sumber air untuk keperluan sehari-hari, dan cara mendapatkan air tersebut dengan bergelantungan pada cadas tersebut.

3) Flora

Penamaan yang menggunakan nama tumbuhan sebagai nama objek wisata, misalkan di data ditemukan seperti ampar nangka, batu tulip, warujimun.

(18) Ampar nangka

Ampah Nangka merupakan nama objek wisata dengan mengadopsi nama tumbuhan, yaitu nangka. Menurut $\mathrm{KBBI}$ nangka merupakan pohon yang mencapai tinggi 10-15 meter, kayunya berwarna kuning dana berkulit hitam. Daunnya kaku agak bundar sebesar tapak tangan orang dewasa berwarna hijau tua, kulit buahnya berduri yang tidak tajam dan bergetah, buah yang muda untuk sayur, sedangkan yang masak dimakan sebagai buah.

(19) Tulip

Tulip merupakan bunga anggota keluarga lili, berwarna cerah dengan mahkota menyerupai bola lampu, biasa berbunga saat musim semi;

(20) Waru

Waru pohon kecil, bias tumbuh dihutan, kayunya digunakan untuk bahan bakar, serat kulit biasa digunakan untuk tali.

4) Fauna

(21) Talaga remis

Dalam Bahasa Sunda Talaga mempunyai arti situ alam anu jadi ku maneh, lain menang nyieun jelema (LBBS, 2010:464). Dapat diartikan dalam Bahasa Indonesia bahwa Talaga merupakan sebuah kolam yang terbentuk secara alami tanpa campur tangan manusia. Remis ( $n$ ) karang yang dapat dimakan 
(22) Leuweung monyet

Leuweung ( $n$ ) berarti 'hutan' atau lahan yang luas yang masih ditinggali berbagai jenis hewan.

Monyet $(n)$ yang berarti kera yang bulunya berwarna keabu-abuan dan berekor panjang.

(23) Talaga nilem

Talaga (n) merupakan sebuah kolam yang terbentuk secara alami tanpa campur tangan manusia.

Nilem (n) ikan air tawar.

(24) Curug bangkong

Curug $(\mathrm{n})$ adalah cai walungan nu turun kana jurang cara pancuran (LBBS, 2010;1001). Dalam Bahasa Indonesia dikenal dengan nama Air Terjun. Yang artinya adalah aliran air melewati jeram hingga air jatuh bebas ke dasar sungai (lereng, lembah). Bangkong (n) yang artinya 'Katak/kodok'.

\section{Analisis makna berdasarkan teori Ogden dan Richards (1923).}

Dalam teori ini istilah yang digunakan adalah (a) Symbol, (b) Thought or Reference (c) Referent. Ogden dan Richards telah menemukan cara untuk menghubungkan semua kata dengan maknanya.

(25) Cibulan

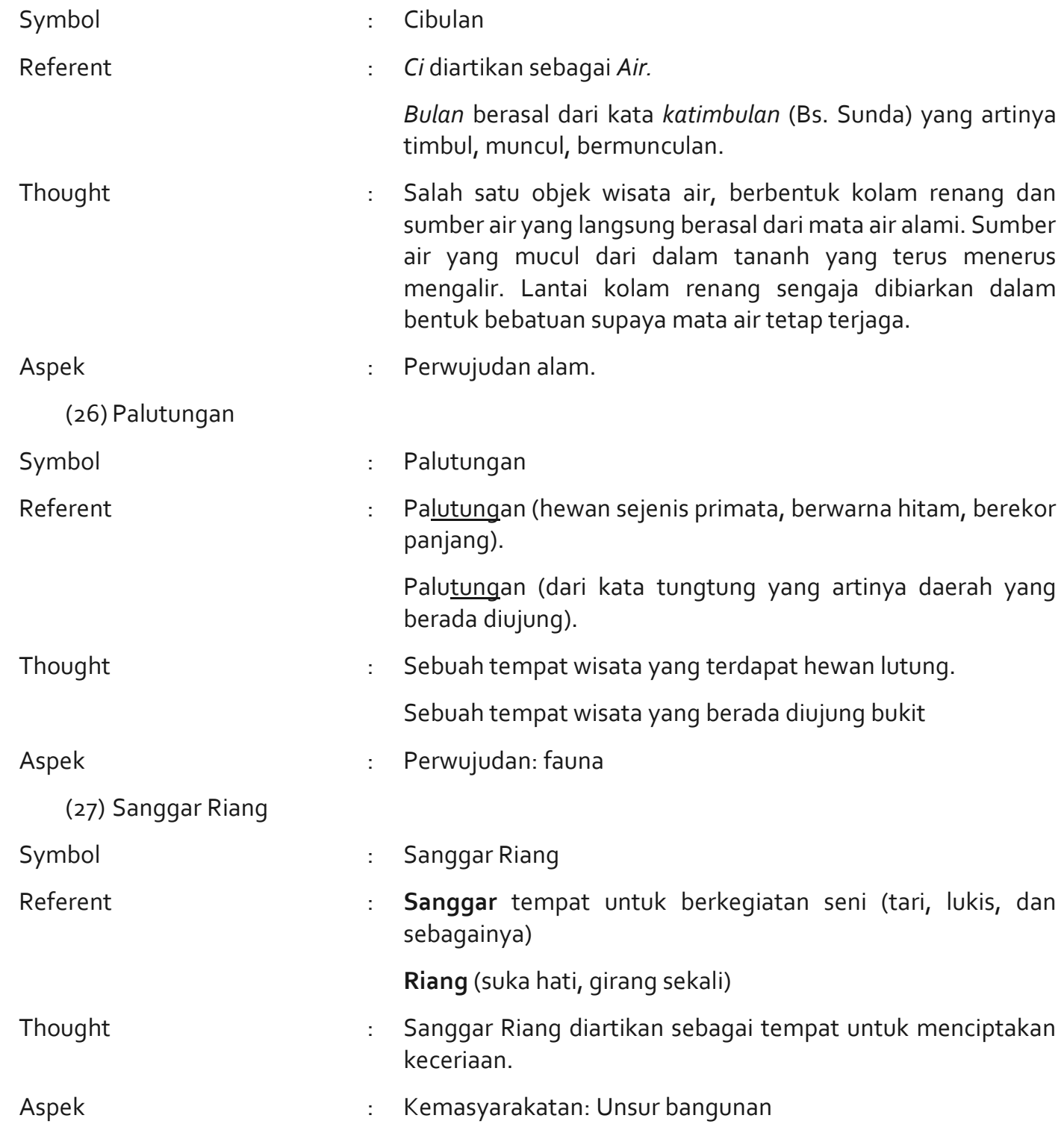


Didit Aditya

(28) Curug Landung

Symbol

Referent

Thought

Aspek

(29) The Mountain Park

Symbol

Referent

Thought

Aspek

(30) Sukageuri View

Symbol

Referent

Thought

Aspek

(31) J n J

Symbol

Referent

Thought

Aspek
: Curug Landung

: Curug dalam Bahasa Indonesia artinya air terjun

Landung artinya panjang ke bawah. Dalam Bahasa Sunda Landung - Rambut panjang.

: Air terjun yang ukurannya panjang seperti rambut yang terurai.

: Kebudayaan: Folklor

: The Mountain Park

: Mountain artinya Gunung

Park artinya Taman

: $\quad$ The Mountain Park merupakan salah satu objek wisata di kaki Gunung Ciremai. Pemandangan yang ditawarkan adalah taman yang berdekatan dengan gunung.

: Perwujudan: Unsur Benda alam

: Sukageuri View

: Suka artinya senang, bahagia

geuri berasal dari kata Seuri yang artinya tertawa bahagia

View yang artinya pemandangan

: Sukageuri View adalah objek wisata bentuk bukit yang menampilkan pemandangan Kota Kuningan dari atas bukit kaki Gunung Ciremai.

: Kemasyarakatan: Harapan

: JnJ

: J n J artinya Jul Jol.

Jul diartikan menjadi dua arti yang pertama dari Bahasa Sunda yang artinya adalah 'keluar' dan yang kedua artinya Jonathan (anak pemilik objek wisata).

Jol menjadi dua arti yang pertama dari Bahasa Sunda yang artinya adalah 'masuk' dan yang kedua artinya Joshwa (anak pemilik objek wisata)

: J n J adalah objek wisata yang menawarkan wahana kolam renamg, beberapa hewan khusus seperti kebun binatang. Jul Jol sendiri yang artinga Keluar Masuk dengan harapan tempatnya selalu ramai karena pengunjung keluar masuk tanpa henti.

: Kemasyarakatan: Harapan 
(32) Zam Zam Pool

$\begin{aligned} \text { Symbol } & : \text { Kolam Renang Zam Zam Pool } \\ \text { Referent } & : \text { Zam Zam (n) yang artinya berkumpul. } \\ & \text { Pool (n) yang artinya kolam. } \\ \text { Thought } & \text { Zam zam pool adalah salah satu objek wisata terbaru di } \\ & \text { Kabupaten Kuningan Jawa Barat. Penamaan Zam Zam Pool } \\ & \text { dilatarbelakangi oleh bagaimana tempat tersebut terbentuk. } \\ & \text { Penaman Zam Zam dikarenakan sumber mata air yang } \\ & \text { terdapat di kolam tersebut berlimpah dan berkumpul seperti } \\ & \text { Zam Zam di Mekah. } \\ & \text { Kemasyarakatan: Harapan } \\ \text { Aspek } & \text { Ampah Nangka } \\ \text { Symbol } & \text { Ampah (adv) yang artinya datar atau rata. } \\ \text { Referent } & \text { Nangka (n) jenis buah yang rasanya manis, nangka muda } \\ & \text { biasa disayur. } \\ & \text { Ampah Nangka dilatarbelakangi oleh lokasi yan berupa } \\ \text { dataran rendah berbentuk datar atau rata dan terdapat } & \text { banyak pohon nangka. } \\ \text { Aspek } & \text { Perwujudan: flora. } \\ & \text { Perwujudan alam. }\end{aligned}$

\section{KESIMPULAN}

1. Bentuk satuan kebahasaan terdiri dari kata dan morfem. Terdapat satu sampai lima kata yang digunakan dalam penamaan objek wisata di Kabupaten Kuningan. Kata yang mengalami proses morfologi dengan penambahan afiksasi. Dan ditemukan juga morfem yang berjumlah satu sampai lima morfem. Data terbanyak menunjukkan penggunaan dua kata dan dua morfem. Hal ini diharapkan untuk memudahkan para pengunjung mengingat nama-nama tersebut. Masih menggunakan Bahasa daerah yaitu Bahasa Sunda.

2. Dari hasil analisis makna, terdapat kategorisasi makna yang terdiri dari 1) Aspek perwujudan yang terdiri dari wujud air, wujud muka bumi, flora, fauna dan benda alam, 2) Aspek kemasyarakatan terdiri dari profesi, harapan, kegiatan, dan unsur bangunan, 3) Aspek kebudayaan : folklore, mitologi, dan religi.

3. Dilihat dari Symbol, Referent, dan Thought makna nama-nama objek wisata di Kabupaten Kuningan memiliki hubungan dengan nilai sosial, budaya, dan perkembangan zaman. Dimana pengembangan objek wisata sedang digalakan besar-besaran baik itu oleh pemerintah maupun swasta sehingga meunculkan nama-nama baru objek wisata.

4. Sistem penamaan objek wisata di wilayah Kabupaten Kuningan didasarkan pada cerita masyarakat dan kondisi alam.

5. Dinamika yang terjadi adalah penggunaan Bahasa asing dalam penamaan objek wisata yang dianggap kekinian dan berharap diterima masyarakat luar.

\section{DAFTAR PUSTAKA}

Chaer, Abdul. 2007. Linguistik Umum. Jakarta: Rineka Cipta.

Kosasih, Dede. 2010. Kosmologi Sistem Nama Diri (antroponim) Masyarakat Sunda: dalam Konstelasi Perubahan Struktur Sosial Budaya". Seminar Hari Ibu. Bandung: Universitas Pendidikan Indonesia.

Djajasudarma, Fatimah. T. 1993. Semantik 1: Pengantar ke Arah Ilmu Makna. Bandung: PT. Eresco. 
Didit Aditya

Kridalaksana, Harimurti. 2008. Kamus Linguistik. Jakarta: PT. Gramedia Pustaka Utama.

Mardhoniawati, Alifa. 2016. "Toponimi Desa-Desa di Lampung: Sebuah Kajian Linguistik Antropologi". (Tesis Fakultas Ilmu Budaya Universitas Gadjah Mada). Yogyakarta.

Ogden, C. K. \& Richards, I. A. 1923. The Meaning of Meaning. 8th Ed. New York, Harcourt, Brace \& World, Inc.

Sudaryanto. 1986. Metode Linguistik Bagian Pertama Ke Arah Memahami Metode Linguistik. Yogyakarta: UGM Press.

Sudaryanto. 1988. Metode Linguistik Bagian Kedua Metode dan Aneka Teknik Pengumpulan Data. Yogyakarta: UGM Press.

Sudaryanto. 2015. Metode dan Aneka Teknik Analisis Bahasa: Pengantar Penelitian Wahana Kebudayaan Secara Linguistis. Yogyakarta: USD Press

Sudaryat, Yayat, dkk. 2009. Toponimi Jawa Barat (Berdasarkan cerita Rakyat). Bandung: Dinas Pariwiata dan Kebudayaan Provinsi Jawa Barat.

Permadi, Tedi. 2012. "Toponimi Jalan Raya di Bandung". Bandung: Fakultas Pendidikan Bahasa dan Seni Universitas Pendidikan Indonesia.

Wijana, I Dewa Putu. 2015. Pengantar Semantik Bahasa Indonesia. Yogyakarta: Penerbit Pustaka Pelajar.

Wijana, I Dewa Putu. 2016. Metode Linguistik: Identifikasi Satuan-Satuan Lingual. Yogyakarta: A.Com Advertising Yogyakarta. 